\title{
Primary cause of cotyledonous bacterial blight on soybean
}

\author{
Sergey Zelentsov, Galina Saenko*, and Elena Moshnenko \\ V.S. Pustovoit All-Russian Research Institute of Oil Crops, 350038, 17, Filatov, St., Krasnodar, \\ Russian Federation
}

\begin{abstract}
One of the main causes of the worldwide decrease of sowing quality of soybean seeds is a cotyledonous bacterial blight in the form of necrotic decaying spots on the outer or inner side of cotyledons. We hypothesize that there is a primary non-bacterial cause for the development of necrotic spots on cotyledons of soybean seeds. We carried out the research in 2016-2020 at V.S. Pustovoit All-Russian Research Institute of Oil Crops on soybean seeds. Cotyledonous bacterial blight is never recorded on immature seeds of healthy soybean plants at the stages of a complete filling and the beginning of physiological maturation. But the secondary (rain) moistening of mature seeds on unharvested plants leads to the development of cotyledonous necroses and a decrease of soybean seed germination due to the subsequent necrotization of over-moistened and repeatedly dried tissues of cotyledons. The physiological mechanism of cotyledon necrosis formation is based on the secondary moistening of individual areas or whole mature seeds to a critical moisture level that initiates nucleic acid synthesis. This irreversibly activates the cell division processes of the over-moistened areas of cotyledons. Subsequent drying of seeds with over-moistened areas of cotyledons leads to their necrosis. The isolation of bacterial pathogens of various species and families in the necrotic areas of cotyledons can be explained by the secondary saprophytic infection of the over-moistened tissues already dead after secondary drying.
\end{abstract}

\section{Introduction}

Soybean is the world's most highly demanded and main leguminous crop. In 2019, according to the FAO, soybean is cultivated in 97 countries and has a crop acreage of more than 120.5 million hectares. This represents $57.5 \%$ of the total acreage of leguminous crops in the world. The gross yield of soybean in 2019 amounted to 333.7 million tons or more than $79 \%$ of the world's total gross yield of leguminous crops. The total annual demand for soybean seed material, even with a minimum seeding rate of $50 \mathrm{~kg} / \mathrm{ha}$, is at least 10.5 million tons [1].

To ensure a specified density and uniform distribution of plants in the sowing, national standards for the sowing quality of seeds of leguminous crops in almost all developed

\footnotetext{
* Corresponding author: saenkogm@mail.ru
} 
countries stipulate certain germination thresholds below which the seed material is not allowed for sowing. In particular, the Russian State Standard R 52325-2005 "Seeds of agricultural plants. Variety and sowing qualities" defines the minimum germination of soybean seeds as not less than $80 \%$ [2].

The U.S. Federal Seed Act stipulates that the minimum germination of soybean seeds must be at least $75 \%$ [3]. In all national regulations of the soybean-producing countries, it is recorded that some of the crop seeds have injuries of cotyledons and axial organs of an embryo that prevent their germination. Therefore, almost all of the world's soybean acreage is sown with seeds with less than $100 \%$ germination.

There are many reasons for the decreased sowing qualities of soybean seeds. Among them are unfavorable abiotic and biotic factors during the period of seed formation, filling, and ripening (drought-induced shriveling, frost damage, hail damage, insect damage, etc.); mechanical seed injuries during combine harvesting, transportation and conditioning; as well as fungal, bacterial and viral diseases.

One of the significant phytopathogenic causes of seed sowing qualities decrease in soybean is cotyledonous bacterial blight. Seed bacterial infestations are depressed spots or ulcers of various sizes and configurations on the outer and/or inner surface of cotyledons. The color of spots varies from grey and light yellow to brown and black. Frequently, bacterial spots and ulcers are noted on the seedling hypocotyl. Bacterial seed infection is capable of spreading to vegetative plants and affecting stems, leaves, and pods with the seeds of the next generation [4-9].

The International Seed Testing Association (ISTA) methodology identifies the signs of varying degrees of abnormal bacterial necrosis of soybean cotyledons typical of all soybean-growing countries [10] (Fig. 1).
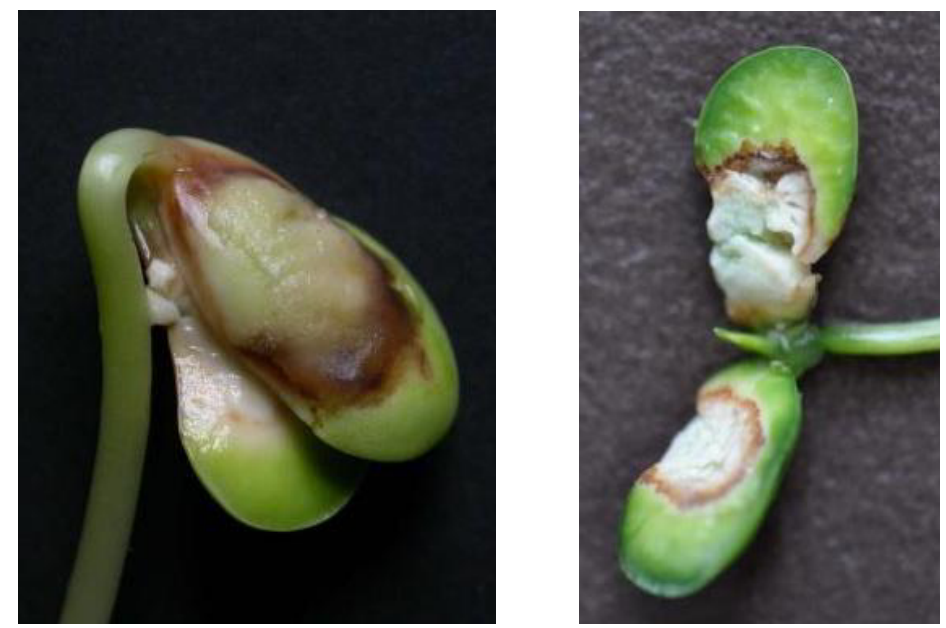

Fig. 1. Fixation of the development of necrosis of cotyledons of soybean seedlings according to the methodology of the International Seed Testing Association (ISTA), Switzerland [10].

Soybean bacterial blight is known in almost all countries and regions where the crop is cultivated. Numerous studies have established the main list of bacterial species identified in affected plant parts, including pods and seeds.

Among them are Pseudomonas savastanoi pv. glycinea (Coerper) Young et al.; Xanthomonas axonopodis pv. glycines (Nacano) Vauterin et al.; Pseudomonas syringae pv. tabaci (Wolf \& Ferster) Young et al.; Curtobacterium flaccumfaciens pv. flaccumfaciens (Hedges) Collins \& Jones; Ralstonia solanacearum (E. F. Smith) Yabuuchi et al.; Bacillus subtilis (Ehrenberg) Cohn. [11-12]. 
However, during the studying and describing the species composition of pathogens of bacterial blight of soybean and other leguminous crops, the main attention, as a rule, was paid to bacterial affection of vegetative plant parts - shoots and leaves, less often - pod valves. Most often, the authors of such studies noted without much detail that, one way or another, pathogenic bacteria from affected plant parts can get to the surface of seeds and cause the development of cotyledonous bacterial blight. At the same time, the mechanisms and ways of penetration of pathogenic bacteria from affected leaves and stems under the seed coating and their development in infected tissues of cotyledons remain poorly studied. Only a few studies have also been published on the infection of seeds of leguminous crops through direct contact with pod valves affected with bacterial blight [13-16].

In general, an analysis of the available publications on bacterial blight of soybean and other leguminous crops shows that regardless of the botanical species of the legumes, the symptoms of bacterial blight on seeds are largely similar and mainly manifest in the formation of necrotic decaying spots or ulcers on the outer or inner surface of cotyledons, often affecting the axial organs of embryos.

Not specialized nature of the pathogens is a characteristic feature of bacterial blight of soybean and other leguminous crops. Various pathogenic bacterial species with similar symptoms are isolated from affected plant tissues, including those belonging to different families: Pseudomonadaceae Winslow et al.; Microbacteriaceae Park et al.; Enterobacteriaceae Rahn; Bacillaceae Garrity et al.; Corynebacteriaceae Lehmann \& Neumann.

There is a practical absence of information about the mechanisms and ways of penetration of bacterial blight pathogens under the coatings of healthy seeds of soybean and other leguminous crops, except for direct contact with the inner surfaces of pod valves infected with bacterial blight.

All the above-mentioned characteristics suggest some common primary cause of necrotic spots and ulcers on the surface of soybean cotyledons, regardless of the variety and the ecological and geographical area of cultivation and the specific pathogens of bacterial blight.

In a study of soybean seed viability during ontogeny by S.C. Deloushe (1990), it is noted that they begin to decline in germination after reaching the stage of physiological maturity [17]. In the absence of the influence of such biotic factors as primary damage by diseases and pests, the most likely cause of this phenomenon was the high hygroscopic property of mature dry seeds capable of adsorbing moisture from the humid atmosphere or during raining [18-21].

A direct consequence of secondary moistening of mature soybean seeds is the activation of germination enzymes in moistened tissues, similar to the biochemical processes developing in seeds sown in moist soil [18-19, 22-26]. In moistened seed tissues (cotyledons, axial organs of embryos), processes of nucleic acid synthesis initiation and preparation for the first cell division are initiated with different intensity, depending on the degree of moistening [23-24, 27]. Having reached this stage, moistened areas of seeds irreversibly transformed into the category of plant tissues, and with a subsequent decrease in moisture, they do not return to the dormant state but die off similarly to dried tissues of vegetative plants $[18,23,27-28]$.

Thus, secondary rain or dew moistening of mature soybean seeds may be the primary cause of dying off of cotyledon tissue areas that have reached the stage of beginning nucleic acid synthesis. The hypothesis of the formation of necrotic areas on secondary moistened cotyledons of mature seeds of soybean and leguminous crops as the primary cause of cotyledonous bacterial blight, formulated with the above-mentioned characteristics in mind, is the purpose of the present research. 


\section{Methods}

We carried out the research in 2016-2020 at V.S. Pustovoit All-Russian Research Institute of Oil Crops, Krasnodar. We evaluated the development dynamics of cotyledonous bacterial blight on soybean varieties Lira, Slavia and Vilana. For this purpose, at the breeding plots of varieties, during the stage of a complete filling of seeds, we selected and marked the uniform areas without visible signs of bacterial blight on leaves, stems and pods. In these areas, we randomly selected 25 plants of each variety and we manually harvested all pods at the stages of a complete seed filling, physiological maturity, full ripening, and monthly overmature stand. The green and yellow moistened pods harvested at the stages of filling and physiological maturity were dried at room temperature. After harvesting the last group of pods from the plants that overmatured for 30 days, all the pods were placed in storage for 2 months, then they were opened, and seeds were extracted. Seeds of all variants were simultaneously placed on wet filter paper and soaked for 3 days until the stage of radicle growth. Then, we removed seed coatings from the seeds and recorded the presence of necrotic spots on cotyledons.

We studied the effect of secondary moistening of mature soybean seeds (variety Vilana) on necrosis development of cotyledons by artificial local and continuous moistening as well as by the different duration of continuous moistening. To imitate short and continuous precipitation with water penetration through the pod valves, we placed soybean seeds in water for 10 minutes, 1 and 4 hours in 3 replications in the amount of 250 pieces of each variant. Of the total number of seeds in each moistening variant, we kept 200 seeds for further studies, and we used 50 seeds to determine the achieved total moisture content by weight method.

As an additional variant, we applied local (dripping) moistening of the side surfaces of soybean seeds in the amount of 30-40 $\mu$ for each seed. For each variant, we locally moistened 50 seeds in 3 replications.

In each moistening variant, we additionally soaked 10 seeds to visually record the dynamics of change in moistened tissue area on the cross-section of the seeds.

We dried all samples of seeds after different regimes of secondary moistening at room temperature and kept them in storage. Then, we selected 50 seeds for each variant every 10 days for 40 days and germinated them for 5 days in a growth chamber on a filter paper. After germination, we determined the laboratory germination of each seed sample, and we counted the number of seeds with cotyledon necroses.

\section{Results}

Long-term field observations of soybean seed formation and filling show that on immature seeds of healthy plants at the stages of a complete filling and the beginning of physiological maturation, necrotic areas that can be qualified as cotyledonous bacterial blight are almost never noted visually. Damage of immature seeds by insect pests is observed only in isolated cases. Domestic and foreign scientific literature also lacks information on the occurrence of cotyledonous bacterial blight on immature moist seeds of soybean and other leguminous plants without signs of bacterial blights on the vegetative parts. However, bacterial blight has already been noted on mature seeds of similarly healthy plants, especially if they had an overmatured stand in the field for a certain time after ripening and have been subjected to periodic precipitation.

To confirm and systemize our previous observations, in 2016-2017, we carried out a model experiment on three soybean varieties Lira, Slavia and Vilana to evaluate the frequency of occurrence of cotyledonous necrosis ("bacterial blight") on soybean seeds at 
different stages of ontogenesis and the effect of harvesting time on the development of this trait (Table 1).

Table 1. Effect of development stages and harvesting time on the natural formation of cotyledonous necroses on soybean seeds (V.S. Pustovoit All-Russian Research Institute of Oil Crops, 2016-2017).

\begin{tabular}{|l|c|c|c|c|c|}
\hline \multirow{2}{*}{$\begin{array}{c}\text { Variety } \\
\text { sample }\end{array}$} & \multirow{5}{*}{ Year } & \multicolumn{5}{|c|}{ The presence of necrosis on cotyledons when harvesting seeds at } \\
various time, \% \\
\cline { 4 - 6 }
\end{tabular}

The table shows the complete absence of any necrotic spots on the cotyledons of all studied soybean varieties, both of immature green seeds at the stage of a complete filling and of seeds that have already acquired the typical yellow color at the physiological maturity stage, but which still have a high moisture content of the tissues. Samples harvested immediately after full ripening at $13-15 \%$ of moisture content already had single seeds with small necrotic spots on the outer surfaces of cotyledons. Seed samples of all three varieties left in the field for one month after ripening showed typical cotyledonous bacterial blight with a frequency of occurrence of 6 to $16 \%$. In the context of the hypothesis of a negative effect of secondary moistening on the tissues of mature seeds, the development of seed necroses on them can be explained by the precipitation between the onset of full ripening and harvesting.

To further test the hypothesis of dying and decay of cotyledon tissue areas due to secondary rain and dew moistening of fry mature soybean seeds, in 2019-2020, we carried out an experiment to simulate different types of secondary moistening at different intensities and duration of precipitation during the post-ripening period.

The placement of seeds in water for 10 minutes, simulating short-term precipitation or heavy dews, with water penetrating through the pod valves, quite naturally caused an increase in total soybean seed moisture content, on average, of $101 \%$ in comparison to the initial moisture content of control dry seeds (Table 2). Soaking the seeds in water for 1 hour led to an increase in their total moisture content in comparison to the control variant, by 296 relative $\%$. Soaking the seeds for 4 hours, simulating prolonged precipitation for a day or more, increased the total moisture content of soybean seeds to 45.8 absolute \% (478 \% in comparison to the moisture content of dry control seeds).

Table 2. Increase dynamics of soybean seed moisture content under different secondary moistening regimes (V.S. Pustovoit All-Russian Research Institute of Oil Crops, 2019-2020).

\begin{tabular}{|c|c|c|c|c|}
\hline \multirow{3}{*}{ Crop } & \multicolumn{4}{|c|}{ Total moisture content of seeds, \% } \\
\cline { 2 - 5 } & \multirow{2}{*}{$\begin{array}{c}\text { control } \\
\text { (dry seeds) }\end{array}$} & \multicolumn{3}{|c|}{ when soaked in water for: } \\
\cline { 3 - 5 } & 7.8 & 15.7 & $\mathbf{1 ~ h}$ $\mathbf{~ h}$ & $\mathbf{4}$ h \\
\hline Soybean & & 15.9 & 45.8 \\
\hline
\end{tabular}

In addition to the continuous moistening of seeds, we applied local (dripping) moistening of the seed side surfaces with $30-40 \mu 1$ of water per seed as an additional option. 
This moistening variant simulated local water penetration through the microdamages of pod valves and, consequently, local moistening of an individual area of the outer seed surface (Fig. 2).

Fig. 2. Modelling of secondary local moistening of ripened seeds of leguminous crops by applying water drops to their surface (orig.).

When soybean seeds are moistened locally, the coating usually lifts and deforms wavy over the cotyledon surface. Depending on the condition and intactness of coatings, the water drops are completely absorbed by the cotyledon tissues within 20-40 minutes.

Locally moistened cotyledon tissues on cross-sections of seeds are clearly visible against the background of dry tissues as darker spots localized immediately below the coating areas on which we applied water drops (Fig. 3a). In cross-sections of seeds soaked in water for 1 hour, darker areas of wetter tissues of cotyledons were much larger and we observed all over the outer surface of a seed (Fig. 3b). The moistened and enlarged seed coatings that have become elastic are visibly peeling off of the cotyledons. An increase in the diameter of the moistened radicle can be seen on a cross-section of soybean seed.

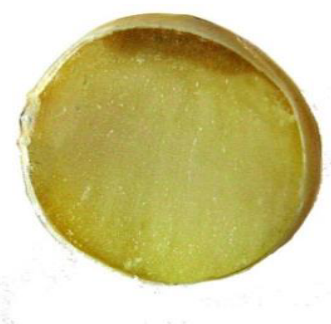

a

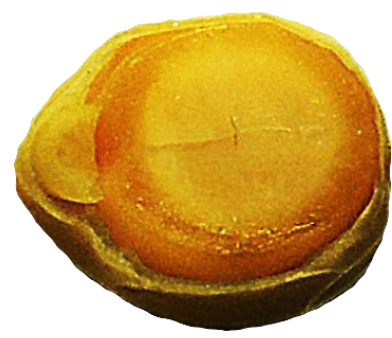

$\mathrm{b}$

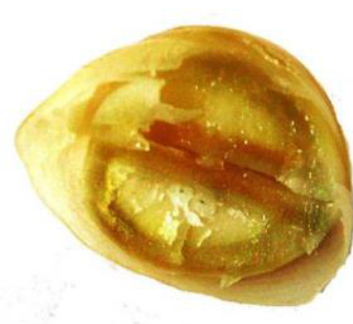

$\mathrm{c}$

Fig. 3 Darkening of soybean seed areas (orig.): a - local swelling of cotyledon tissues (dark areas) with dripping moistening of dry seeds, $\mathrm{b}$ - with continuous peripheral moistening of cotyledon tissues (dark areas) after soaking the seeds for 1 hour, $\mathrm{c}$ - with continuous peripheral moistening of cotyledon tissues (darker areas) after soaking the seeds for 4 hour.

A large volume of cotyledon moistened tissues naturally formed on cross-sections of soybean seeds after 4-hour soaking (Fig. 3c). As can be seen from the appearance of seed cross-sections (Fig. 3c), this soaking period caused the moistening of more than $50 \%$ of the volume of cotyledon tissues. Cross-sections of soybean seeds show moist darkened tissues on the inner surfaces of the cotyledons, followed by their peeling off from each other. Seed coatings were also visibly deformed and volumetrically stretched. 
Based on the analysis of earlier publications [19, 24-25, 27-29] and studied hypothesis, drying of moistened seeds should lead to consequential death and decay of cotyledon areas moistened to the stage of the beginning of nucleic acid synthesis and irreversibly transformed into the category of plant tissues. In this case, the germination of seeds with a large area of necrosis, especially affecting the axial organs of the embryos - radicles and budlets - should be decreased. Analysis of the dynamics of seed germination after secondary soaking generally confirms this conclusion (Table 3).

Table 3. Germination dynamics of dried soybean seeds after different regimes of secondary moistening (V.S. Pustovoit All-Russian Research Institute of Oil Crops, 2019-2020).

\begin{tabular}{|c|c|c|c|c|c|}
\hline \multirow{3}{*}{$\begin{array}{c}\text { Evaluation } \\
\text { period after } \\
\text { secondary } \\
\text { moistening, } \\
\text { days }\end{array}$} & \multicolumn{5}{|c|}{ Seed germination after secondary moistening, \% } \\
\hline & \multirow{2}{*}{$\begin{array}{c}\text { control } \\
\text { (dry seeds) }\end{array}$} & \multirow{2}{*}{$\begin{array}{c}\text { local } \\
\text { moistening } \\
\text { (drop) }\end{array}$} & \multicolumn{3}{|c|}{$\begin{array}{l}\text { continuous soaking for a period of } \\
\text { time: }\end{array}$} \\
\hline & & & $10 \mathrm{~min}$ & $1 \mathrm{~h}$ & $4 \mathrm{~h}$ \\
\hline 10 & 97 & 73 & 69 & 61 & 58 \\
\hline 20 & 96 & 81 & 73 & 66 & 42 \\
\hline 30 & 93 & 70 & 70 & 43 & 38 \\
\hline 40 & 97 & 70 & 70 & 60 & 57 \\
\hline
\end{tabular}

From the data presented in Table 3, the germination capacity of the seeds decreases as the duration of moistening increases. The initial germination of control lots of soybean seeds was $93-97 \%$. Then, we noted a noticeable decrease in germination after secondary moistening. After 4-hour soaking, the germination of seeds in comparison to the level of control seeds decreased by an average of $49 \%$ by the 4 periods of evaluation and amounted to 49 absolute \%. Local moistening of the side surfaces of soybean seeds resulted in a relative decrease of germination by $23 \%$. The timing of seeds placement for germination after secondary moistening at 10-days intervals had practically no noticeable effect on germination.

Generally, during the experiment, secondary moistening of mature seeds resulted in decreased laboratory germination.

A comparative evaluation of the frequency of necrosis formation on soybean cotyledons showed a high negative contribution of secondary moistening in their formation (Table 4).

Table 4. Increase dynamics of formation frequency of cotyledon necroses in soybean after different secondary moistening regimes (V.S. Pustovoit All-Russian Research Institute of Oil Crops, 2019-2020).

\begin{tabular}{|c|c|c|c|c|c|}
\hline \multirow{2}{*}{$\begin{array}{c}\text { Evaluation } \\
\text { period after } \\
\text { secondary } \\
\text { moistening, } \\
\text { days }\end{array}$} & \multicolumn{5}{|c|}{$\begin{array}{c}\text { Formation frequency of cotyledon necroses after secondary } \\
\text { moistening, \% }\end{array}$} \\
\cline { 4 - 6 } & $\begin{array}{c}\text { control } \\
\text { dry seeds) }\end{array}$ & $\begin{array}{c}\text { local moistening } \\
\text { (drop) }\end{array}$ & \multicolumn{2}{c|}{ continuous soaking for a period of } \\
\cline { 4 - 6 } & & 51 & 23 & 62 & $\mathbf{1 0}$ mine: \\
\hline 10 & 13 & 68 & 54 & 72 & 84 \\
\hline 20 & 11 & 71 & 68 & 80 & 86 \\
\hline 30 & 7 & 77 & 63 & 84 & 86 \\
\hline 40 & 12 & & & & \\
\hline
\end{tabular}

Thus, with increasing soaking time, the proportion of soybean seedlings with cotyledon necroses increased by 3.8 times already after a 10-minute soaking compared to the control. After 1 and 4 hours of soaking this indicator in soybean seedlings increased by 5.9 and 6.6. times, respectively. 
Local dripping moistening of side surfaces of soybean seeds also caused an increase in the proportion of cotyledon necroses, comparable with the 1-hour and 4-hour periods of continuous soaking. The timing of seeds placement for germination after secondary moistening, as in the case of laboratory germination, had no noticeable effect on the formation frequency of cotyledon necroses.

Visual analysis of cotyledon necroses of soybean seeds showed an increase in their area and depth with increasing duration of soaking (Fig. 4).

Thus, with a 10-minute soaking and local dripping moistening, cotyledon necroses of seeds were mostly small necrotic spots, usually not affecting the growth of roots and hypocotyls. In certain cases, probably, in the presence of mechanical damage or physiological compensatory ruptures of the seed coat, the area and depth of necroses increased.

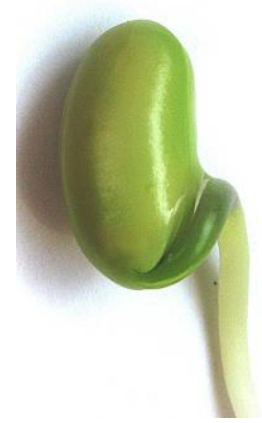

a

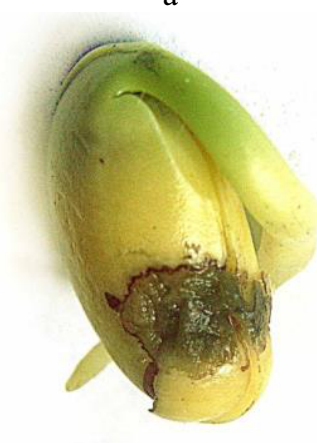

d

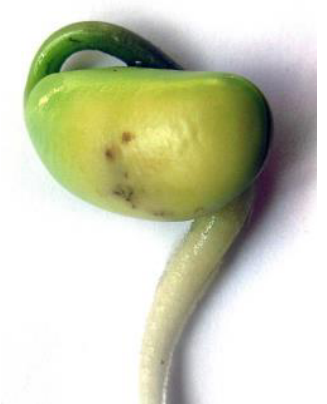

b

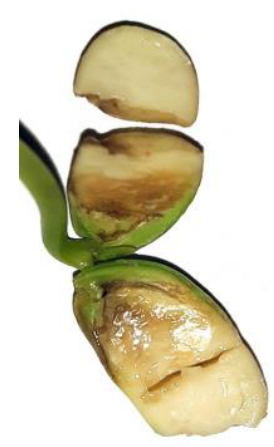

e

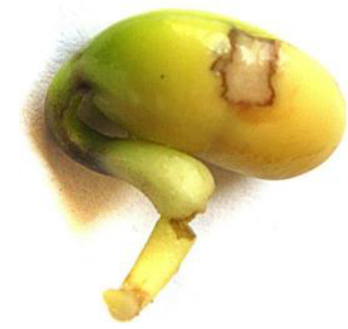

$\mathrm{c}$

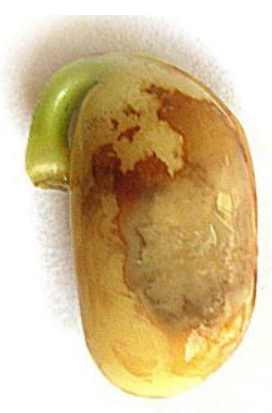

f

Fig. 4. Types of necroses on cotyledons of soybean seedlings formed after secondary moistening (orig.): $\mathrm{a}-$ seedling with healthy cotyledons, $\mathrm{b}-\mathrm{f}-$ necroses of different intensity.

When seeds were soaked for 1 and 4 hours, there was an increase in the proportion of necroses, occupying a larger area of the cotyledon surface, up to their complete coverage. We observed the appearance of necroses penetrating to the inner surface of cotyledons, as well as expressed tissue damage of roots and hypocotyl. We observed the blockage of chlorophyll synthesis in soybean seeds with complete or almost complete coverage of the cotyledons by necroses. 


\section{Discussion}

In general, this research suggests that the common primary cause of necrotic spots and ulcers on the surface of soybean cotyledons, subsequently defined as cotyledonous bacterial blight, is secondary (rain or dew) moistening of mature dry seeds.

The isolation of bacterial pathogens belonging to different species and families in necrotic areas of cotyledons was described multiple times in domestic and foreign publications and can be explained by secondary saprophytic infection of already dead tissues. Therefore, the pathogenic bacterial microflora isolated from the bacterial areas of cotyledons will be determined in each case by the species composition of the bacteria present in the environment (on soil and plant surfaces, in harvesters, harvester bins and augers, in barnyards, in warehouses, in seed-cleaning facilities, in packing containers, etc.).

It is obvious that specific pathogenic bacterial species, which are the primary pathogens, will be isolated from the vegetative parts of the plants (shoots and leaves) as well as from the pod valves with signs of bacterial blight.

Uncontrolled precipitation or heavy dew after soybean maturity, as the primary cause of cotyledonous bacterial blight, limits the effectiveness of control of this disease. The most common measure to control cotyledonous bacterial blight in soybean worldwide is seed treatment with bactericidal preparations before sowing. However, given the results obtained in our research, it is questionable whether bactericidal protectants can have any effect on the secondary moistening of mature seeds. For example, when precipitation falls on mature but not yet harvested plants in the field, as well as inhibiting or blocking the subsequent processes of irreversible necrotization of over-moistened cotyledon tissues.

\section{Conclusion}

Literature analysis shows that the symptoms of bacterial blight on soybean seeds are necrotic decaying spots or ulcers on the outer or inner surface of cotyledons. Various pathogenic species of bacteria, including those belonging to different families, can be isolated from the affected areas with identical symptoms.

We did not observe cotyledonous bacterial blight on immature seeds of healthy soybean plants at the stages of a complete filling and the beginning of physiological maturation. Domestic and foreign scientific literature also lacks information on the facts of detection of cotyledonous bacterial blight on immature moist seeds of soybean and other leguminous crops.

Increasing the intensity and duration of secondary moistening of mature seeds, followed by their drying to storage moisture, leads to an increase in the prevalence of cotyledonous necroses within the over-moistened areas of cotyledons, and a decrease in the germination of soybean seeds.

The affected area and depth of affection of cotyledon tissues of mature soybean seeds increase with increasing duration and intensity of secondary moistening.

The physiological mechanism of cotyledonous necroses formation during the secondary moistening of mature seeds is based on the death of cotyledon areas moistened to the stage of nucleic acid synthesis and irreversibly transformed into the category of plant tissues.

The primary cause of necrotic spots and ulcers on the cotyledon surface of soybean, later classified as cotyledonous bacterial blight, is secondary (rain or dew) moistening of mature seeds.

The isolation of bacterial pathogens belonging to different species and families in necrotic areas of cotyledon can be explained by secondary saprophytic infection of already dead tissues. Therefore, the species composition of the pathogenic microflora will be determined in each case by their presence in the environment. 


\section{References}

1. FAOSTAT, Agricultural crops (2020)

2. State Standard R 52325-2005 Seeds of agricultural plants, Varietal and sowing qualities, General specifications, 24 (2005)

3. Germination standards for vegetable seeds in interstate, Sec. 201.31 commerce (U.S. Federal Seed Act, 1994)

4. M. V. Gorlenko, Bacterial diseases of plants (1966)

5. E. V. Karimova, I. M. Ignatieva, Plant quarantine. Science and practice, 26, 4 (2018)

6. V. G. Kuzmina, FSBSI «Rosselkhozcenter» (2017)

7. L. A. Dega, Soybean diseases and pests, 100 (2014)

8. R. Nettles, J. Watkins, K. Ricks, M. Boyer, M. Licht, L. W. Atwood, M. Peoples, R. G.Smith, D. A. Mortensen, R. T. Koide, Applied Soil Ecology, 102, 7 (2016)

9. J. F. Nicholson, J. B. Sinclair, Phytopathology, 61 (1971)

10. TCOM-P-09, International Seed Testing Asso-ciation (ISTA), CH-Switzerland (2017)

11. G. L. Hartman, J. C. Rupe, E .J. Sikora, L. L. Domier, K. L. Steffey, J. A. Davis, Compendium of Soybean Diseases and Pests (2015)

12. G. L. Hartman The American Phyto-pathological Society (APS) (2015)

1. Food Crop Production by Smallholder Farmers in Southern Africa (2018)

13. T. Belete, K. K. Bastas, Journal of Plant Pathology \& Microbiology, 8 (2017)

14. K. K. Bastas, F. Sahin, European Journal of Plant Pathol-ogy, 147 (2017)

15. C. H.Wohleb, L. J. Du, Toit Washington State University Extension and the U.S. Department of Agriculture, 5 (2011)

16. S. C. Deloushe, Seed Science and Technology, 18 (1990)

17. K. E.Ovcharov, Physiology of seed formation and germination, 256 (1976)

I. G. Strona, Common seed study of field crops, 464 (1966)

18. M. B. Js., McDonald, C. W. Vertucci, E. E. Roos, Crop Science, 28 (1988)

19. E.N. Roberts, Viability of seeds (1982)

20. N. A. Askochenskaya, Seed physiology (1982)

21. N. V. Obrucheva, Seed physiology (1982)

22. S. Ali, A. A. Elozeiri, Advances in Seed Biology (IntechOpen, 2017)

23. D. L. Parish, A. C. Leopold, Plant Physiology, 59 (1977)

24. N. Yamamotoab, T. Takano, T. Masumura, A. Sasou, Sh. Morita, T. Sugimoto, K. Yano, Gene, 762 (2020)

25. S. V. Zelentsov (Abstract of a thesis... PhD in agriculture, 1995)

26. V. Kochegura, S. V. Zelentsov, Oil crops, 116 (1995) 